\title{
UNIVERISTY OF NEBRASKA-LINCOLN FUNDAMENTALS OF GEOSCIENCE IN THE FIELD AND Methods IN GEOSCIENCE FIELD INSTRUCTION
}

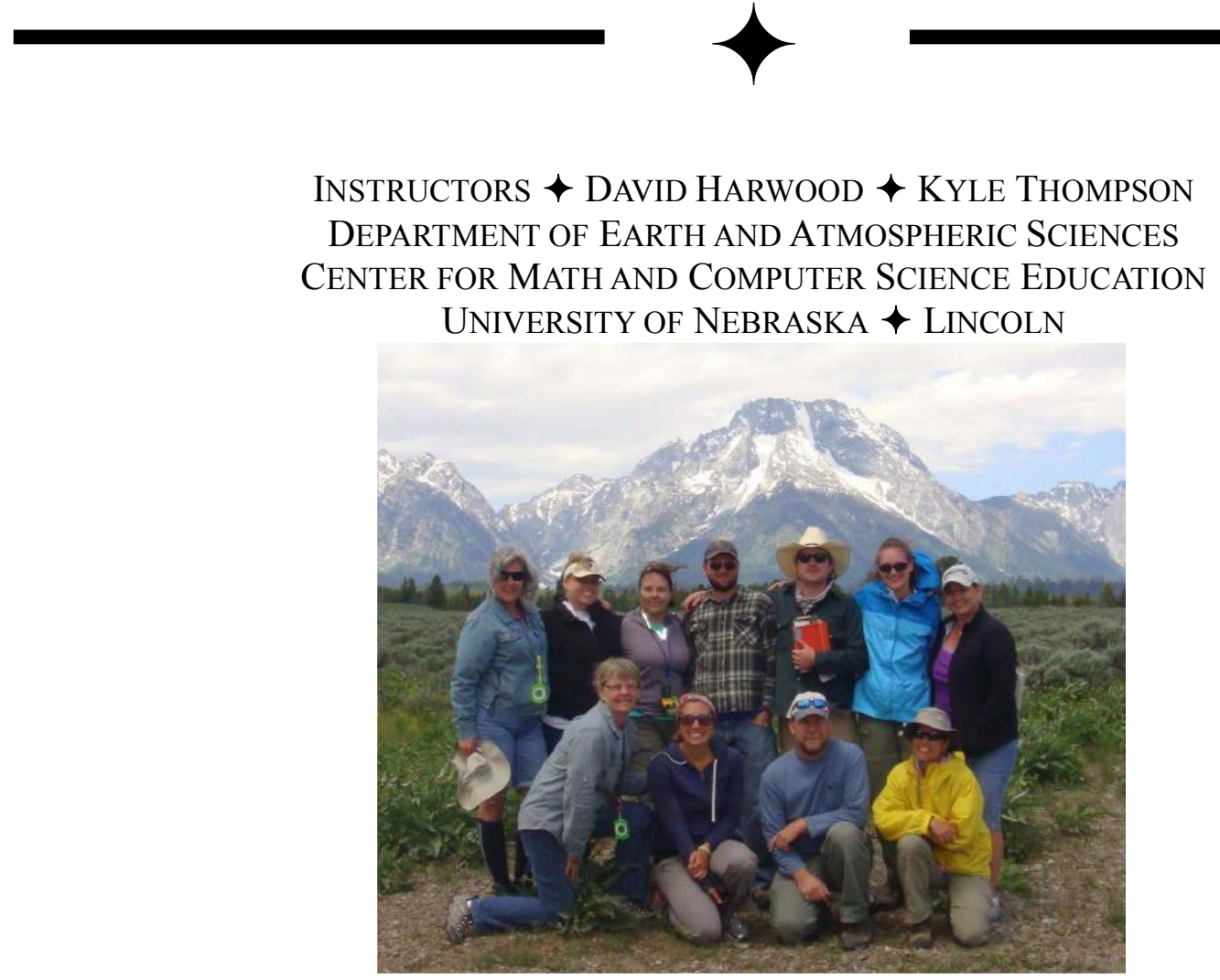

Students with Mount Moran in the background.

\section{$\uparrow$ Class OVerview}

This field course offers in-service teachers and pre-service science education majors an opportunity to discover the geological history of the Rocky Mountains and experience inquiry-based geoscience education during a 2-week journey across Wyoming, South Dakota and Nebraska. In 2012 this course utilized the UW-NPS facilities for 3 days in mid-June. The group built upon their growing geological knowledge to investigate the geological evolution of the Teton Range. The 2012 course included six in-service teacher participants (all from Nebraska), two pre-service graduate education majors, and one Geoscience Education Research professor who observed the process. The staff included two instructors and one geology undergraduate teaching assistant. This course is offered through the University of Nebraska-Lincoln's Nebraska Math and Science Summer Institute (NMSSI) Program. This course improves educators' ability to teach inquiry-based science, gain knowledge and understanding of geoscience, and to demonstrate effective teaching methods that can integrate geoscience into K-12 learning environments. The UW-NPS facilities provide an excellent opportunity for participants to discover the natural history of the Teton Range and catch up on fieldbook notes while sitting at a real table - - a welcome change from our normal campground setting. 
Participants became active members of a
field-based learning community comprising individuals with expertise and experience in geoscience and pedagogy. Through a collaborative teaching and learning structure, course participants learned about geoscience, pedagogy, group dynamics, and discovered Rocky Mountain history. The experience was enhanced through the evaluation, assessment and reflection on the inquiry-based approach demonstrated as an effective means of teaching geoscience.

\section{$\uparrow \quad$ Class OBJECTIVES}

Major goals of these courses are: (1) to enhance the 'geoscience experience' for pre-service and in-service science educators, (2) to teach inquiry concepts and skills that K-12 educators are expected to understand and teach (as outlined in national standards), (3) to engage science educators in fieldbased geoscience education and inspire them to use inquiry and geoscience as unifying themes in their classes/teaching activities, (4) to provide participants with an opportunity to pursue authentic geoscience fieldwork, and (5) to enhance pedagogical understanding and provide all participants with a 'toolkit' of effective inquiry-based, and discovery-learning teaching practices. 